\title{
CHITOSAN NANOPARTICLES PREPARED FROM LUCILIA CUPRINA MAGGOTS AS ANTIBACTERIAL AGENT
}

\author{
By
}

MOSTAFA I. HASSAN ${ }^{1 *}$, FATMA A. TAHER ${ }^{2}$, ALY F. MOHAMED ${ }^{3}$

AND MOHAMMAD R. KAMEL ${ }^{1}$

Department of Zoology and Entomology, Faculty of Science ${ }^{1}$ and Department of

Chemistry, Faculty of Science (Girls) ${ }^{2}$, Al-Azhar University, Nasr City and

Applied Researches Sector, Vacsera ${ }^{3}$, Giza, Egypt

( ${ }^{\star}$ Correspondence: mostafa012@gmail.com)

\begin{abstract}
Chitosan were prepared from cuticle of Lucilia cuprina maggots with two steps; deproteinization and deacetylation. It was characterized with solubility and Fourier Transform Infrared spectroscopy (FT-IR). Chitosan was ball-milled to obtain the chitosan nanoparticles which characterized with dynamic light scattering (DLS) and transmission electron microscope (TEM). Chitosan nanoparticles with degree of deacetylation (DDA) $80.5 \%$ were showed antibacterial activities against Klebsiella pneumoniae and Bacillus subtilis. The mode of action of chitosan nanoparticles on the tested bacteria was studied by TEM. Leakage of some cell contents, cell deformation and rupture of cell were observed, therefore, the chitosan nanoparticles were observed to be a powerful antibacterial agent.
\end{abstract}

Keywords: Antibacterial agent, Chitosan nanoparticles, Lucilia cuprina, Maggots

\section{Introduction}

Chitin is the second most important natural polymer in the world and it not soluble in aqueous acidic media. When the degree of deacetylation of chitin reaches about $50 \%$, it becomes soluble in aqueous acidic media and then is called chitosan (Rinaudo, 2006). Traditionally, the chitosan was prepared chemically from the shell of crustaceans by four steps, while the preparation of chitosan from maggots can be processed by two steps.

The cuticle of the maggots is mainly composed of chitin (Jing et al, 2007) that representing the main source of chitosan which is more useful and interesting bioactive polymer (Dutta et al, 2004) because it is a high biodegradable, safe \& antimicrobial agents. Chitosan nanoparticles have been developed as a natural antimicrobial agent, and in vitro results provide promising use for disease treatment (Ma, 2015).

The present study aimed to prepare the chitosan from Lucilia cuprina maggots and investigate the antibacterial activities of chitosan nanoparticles against Klebsiella pneumoniae and Bacillus subtilis and their mode of action using transmission electron microscope.

\section{Materials and Methods}

Collection and Rearing of flies: Lucilia cuprina (Diptera: Calliphoridae) was collected and reared after Hassan, et al. (2013).

Preparation of chitosan: Chitosan powder prepared according to the method of OduorOdote et al. (2005) with some modifications as the following: Second and third larval instars of Lucilia cuprina were collected and stored in freezer at $-20{ }^{\circ} \mathrm{C}$ until homogenization in blender, then dried in oven at $50^{\circ} \mathrm{C}$. The homogenized maggots (Chitin) were sieved and weighted. Deproteinization of chitin: $200 \mathrm{~g}$ from chitin were stirred in 4 liters of sodium hydroxide $2.5 \%$ (w/v) by magnetic stirrer for $2 \mathrm{~h}$ at $50^{\circ} \mathrm{C}$, then filtrated and washed with distilled water until became neutral, and finally washed with absolute ethanol. Step of deprotenization was repeated twice then dried in oven at $50^{\circ} \mathrm{C}$ for 12h. Deacetylation of chitin: $100 \mathrm{~g}$ deproteinized chitin were left in 2 liters of sodium hydroxide $50 \%(\mathrm{w} / \mathrm{v})$ for overnight, and then stirred by magnetic stirrer for a total of $7 \mathrm{~h}$ at $110^{\circ} \mathrm{C}$, then filtrated, washed with distilled water and absolute ethanol. After that, the 
chitosan left for draying in oven at $50^{\circ} \mathrm{C}$ for $12 \mathrm{~h}$ and then weighted.

Characterization of chitosan: The chitosan was characterized with solubility and Fourier transform infrared spectroscopy (FT-IR) analysis. The chitosan sample was tested for solubility in acetic acid $1 \%(\mathrm{v} / \mathrm{v})$ with a ratio 1g: $100 \mathrm{ml}$. It was analyzed by FT-IR JASCO 4100 in wave range $4000-400 \mathrm{~cm}^{-1}$ with resolution of $4 \mathrm{~cm}^{-1}$ at Micro Analytical Center, Faculty of Science, Cairo University. The degree of deacetylation of chitosan was calculated by the equation (1) according to Baxter et al. (1992):

$$
\text { DDA } \%=100-\left[\frac{A_{1655}}{A_{3450}} \times 115\right]
$$

Where:

$\mathrm{A}_{1655}=$ Absorption of band at $1655 \mathrm{~cm}^{-1}$

$\mathrm{A}_{3450}=$ Absorption of band at $3450 \mathrm{~cm}^{-1}$

$\mathrm{A}_{\mathrm{Band}}=-\log ($ Transmittance $)$

Preparation of chitosan nanoparticles: Chitosan nanoparticles were prepared by ballmilling for $8 \mathrm{~h}$ at 3400rpm using Retsch Planetary Ball Mill pm 400 after Zhang et al. (2014) at Egyptian Petroleum Research Institute (EPRI).

Characterization of chitosan nanoparticles: The chitosan nanoparticles were characterized with dynamic light scattering (DLS) after Qi et al. (2004), and transmission electron microscope (TEM) at Egyptian Petroleum Research Institute (EPRI). The chitosan nanoparticles sample was suspended in distilled water then sonicated for $15 \mathrm{~min}$ and measured by Malvern Mastersizer 2000 (Nano-ZS). Morphological characteristics of the chitosan nanoparticles were investigated by transmission electron microscope (Hitachi H-7000, Japan). The chitosan nanoparticles were sonicated in ethanol for 15 min to obtain a dilute suspension. Few drops from a dilute suspension were added on glow discharged carbon-coated microscopy grid and allowed to dry in room temperature then investigated at $200 \mathrm{kV}$.

Antibacterial activity chitosan nanoparticles: The antibacterial activity of chitosan nanoparticles against Klebsiella pneumoniae
(RCMB 01002 23-5) as Gram-negative bacteria and Bacillus subtilis (RCMB 01001 693) as Gram-positive bacteria were evaluated by employing a microdilution method at Unit of Microbiology, The Regional Center of Mycology and Biotechnology, Al-Azhar University, Cairo, Egypt.

Chitosan nanoparticles were dissolved in acetic acid $1 \%(\mathrm{v} / \mathrm{v})$ and diluted to a concentration of $8 \mathrm{mg} / \mathrm{ml}$, further $1: 2$ serial dilutions were performed by addition of culture broth to reach concentrations ranging from 8000 to $0.49 \mu \mathrm{g} / \mathrm{ml}$.

A quantity of $5 \mu$ l of each dilution was distributed in 96 well plates, as well as a sterility control and a growth control (containing culture broth plus acetic acid 1\% (v/v), without antimicrobial substance). Each test and growth control well was inoculated with $5 \mu \mathrm{l}$ of microbial suspension $\left(10^{5} \mathrm{CFU} /\right.$ well). All experiments were performed in triplicate and the microdilution trays were incubated at $37^{\circ} \mathrm{C}$ for $24 \mathrm{~h}$ after Souza et al. (2005). Ten $\mu 1$ of 3- (4,5-Dimethylthiazol-2yl)-2,5-diphenyltetrazolium bromide (MTT) solution $(5 \mathrm{mg} / \mathrm{ml})$ were added to each well and the plates were re-incubated for $3 \mathrm{~h}$ at $37^{\circ} \mathrm{C}$.

Fifty $\mu$ l of Dimethyl sulfoxide (DMSO) solution were added to these wells and microbial growth was detected by optical density (ELISA reader, Tecan, Sunrise Remote/ Touch screen).

Electron microscopy examination: Klebsiella pneumoniae and Bacillus subtilis were treated with $125 \mu \mathrm{g}$ and prepared for electron microscopy examination (Helander et al, 2001).

\section{Results}

Solubility: The chitosan sample was soluble immediately without heating or sonication in $1 \%$ acetic acid (v/v) with ratio $1 \mathrm{~g}$ $/ 100 \mathrm{ml}$. This result indicated to the sample was chitosan powder with degree of deacetylation above $50 \%$.

Fourier transform infrared spectroscopy (FT-IR) analysis: FT-IR spectrum of tested chitosan was shown (Fig. 1) and the main 
peaks for chitosan functional groups; stretching of $\mathrm{NH} \& \mathrm{OH}$ Free, asymmetric stretching of $\mathrm{CH}(-\mathrm{CH} 2)$, bending of $\mathrm{NH}$ (R$\mathrm{NH} 2)$, asymmetric bending of $\mathrm{CH}(-\mathrm{CH} 2)$, symmetric bending of $\mathrm{CH}(-\mathrm{CH} 2)$, stretching of $\mathrm{CN}$ or bending of $\mathrm{OH}$, symmetric stretching of (C-O-C), stretching of $(\mathrm{C} 3-\mathrm{O}) \mathrm{OH}$ group, stretching of (C6-O) $\mathrm{OH}$ group and vibration of pyranose ring skeletal were detected at bands: 3440, 2922, 1596, 1424, $1381,1253,1152,1091,1035$ and $896 \mathrm{~cm}^{-1}$, respectively.

The absence of band absorption at 1540 $\mathrm{cm}^{-1}$ indicated successful deproteinization for chitin. The main functional groups which used in differentiation between chitin and chitosan were $\left(\mathrm{C}=\mathrm{O} \rightarrow \mathrm{NHCOCH}_{3}\right)$ amide group at band around $1660 \mathrm{~cm}^{-1}$ and $\left(\mathrm{NH}_{2}\right)$ amine group at band around $1600 \mathrm{~cm}^{-1}$. The high intensity of band at $1596 \mathrm{~cm}-1$ in FTIR and absence of absorption band around $1660 \mathrm{~cm}-1$ was indicated to the presence of the $\mathrm{NH}_{2}$ group and the success of the deacetylation process of chitin. After calculation the degree of deacetylation (DDA) of chitosan by equation (1), the DDA of chitosan sample is $80.5 \%$.
Dynamic light scattering (DLS) analysis: The number-weighted distributions of particle size and particle size distributions of chitosan nanoparticles batches were measured by dynamic light scattering, and it showed one major peak at $53.59 \mathrm{~nm}$ that represented $98.2 \%$ from the sample (Fig. 2).

Transmission Electron Microscope (TEM) analysis: The investigation of chitosan nanoparticles by TEM showed the homogenous cubic shape particles with width ranged between $16.33 \mathrm{~nm}$ to $30.73 \mathrm{~nm}$ (Fig. 3).

Chitosan nanoparticles showed antibacterial activities against Klebsiella pneumoniae and Bacillus subtilis. The effect of chitosan nanoparticles on Klebsiella pneumoniae was began at concentration $1.95 \mu \mathrm{g} / \mathrm{ml}$ and showed $16.75 \%$ inhibition. The completely inhibition of $K$. pneumoniae was recorded at concentrations 250, 500, 1000, 2000, 4000 and $8000 \mu \mathrm{g} / \mathrm{ml}$, while, the effect of chitosan nanoparticles on Bacillus subtilis was recorded at concentration $31.25 \mu \mathrm{g} / \mathrm{ml}$ and increased with the increasing of concentration until showed $100 \%$ inhibition at concentrations 4000 and $8000 \mu \mathrm{g} / \mathrm{ml}$ (Tab. 1; Fig. 4).

Table 1: Antibacterial activities of chitosan nanoparticles against Klebsiella pneumoniae and Bacillus subtilis

\begin{tabular}{|l|c|c|}
\hline \multirow{2}{*}{ Concentration $(\mu \mathrm{g} / \mathrm{ml})$} & \multicolumn{2}{|c|}{ Inhibition $(\%)$} \\
\cline { 2 - 3 } & Klebsiella pneumoniae & Bacillus subtilis \\
\hline 8000 & 100 & 100 \\
\hline 4000 & 100 & 100 \\
\hline 2000 & 100 & 90.68 \\
\hline 1000 & 100 & 87.66 \\
\hline 500 & 100 & 70.17 \\
\hline 250 & 100 & 56.75 \\
\hline 125 & 93.13 & 45.02 \\
\hline 62.5 & 83.68 & 16.36 \\
\hline 31.25 & 68.37 & 7.65 \\
\hline 15.63 & 48.77 & - \\
\hline 7.81 & 37.86 & - \\
\hline 3.9 & 27.81 & - \\
\hline 1.95 & 16.75 & - \\
\hline 0.98 & - & - \\
\hline 0.49 & - & - \\
\hline
\end{tabular}

Electron microscopy examination: Morphological changes were observed in treated bacteria; Klebsiella pneumoniae (RCMB 01002 23-5] and Bacillus subtilis (RCMB
01001 69-3) with chitosan nanoparticles (Fig. 5 B \& D), respectively. Chitosan nanoparticles increased the permeability of the bacteria and led to leakage of cell contents, 
cell deformation and rupture of cell. Both longitudinal section (LS) and transverse section (TS) of untreated (Control) Klebsiella pneumoniae and Bacillus subtilis were shown in figure (5 A and C), respectively. Intact and apparent bacterial cell walls (CW) and cell membrane (CM) were observed. Also, concentrated bacterial contents (BC) were clearly observed.

\section{Discussion}

Solubility: Generally, solubility in organic acid such as acetic acid is primary analysis for differentiation between chitin and chitosan, where, the chitosan has the ability to soluble in organic acid while the chitin has not this ability.

According to the experimental procedures, both chitosan and chitosan nanoparticles samples were dissolved in $1 \%$ acetic acid. Hence; in agreement with Peter, (1995), the solubility of chitosan in acetic acid $1 \%$ was indicated the chitosan has degree of deacetylation above $50 \%$.

Fourier Transform Infrared (FT-IR) spectroscopy analysis, agreed with Gylienë et al. (2003); Zvezdova (2010); Zhang et al. (2011); Liu et al. (2013); Song et al. (2013); Hafsa et al. (2014); Wanule et al. (2014) and Kaya et al. (2015) the broad peak around $3440 \mathrm{~cm}^{-1}$ was represented the stretching vibration of $\mathrm{NH}$ and $\mathrm{OH}$ groups in chitosan.

The asymmetric stretching vibration of $\mathrm{CH}$ $\left(-\mathrm{CH}_{2}\right)$ was observed at peak around 2922 $\mathrm{cm}^{-1}$, this result agreed with Dong et al. (2001); Gylienë et al. (2003); Zvezdova (2010); Liu et al. (2013); Song et al. (2013); Wanule et al. (2014) and Kaya et al. (2015). The detection of the bending vibration for $\mathrm{NH}\left(\mathrm{R}-\mathrm{NH}_{2}\right)$ at beak around peak $1596 \mathrm{~cm}^{-1}$ was matched with Jia and $\mathrm{Xu}$ (2001); Gylienë et al. (2003); Liu et al. (2013); Song et al. (2013); Subhapradha et al. (2013) and Kaya et al. (2015).

Corresponding with Dong et al. (2001); Gylienë et al. (2003); Zvezdova (2010); Liu et al. (2013) and Kaya et al. (2015), the bending vibration of $\mathrm{CH}\left(-\mathrm{CH}_{2}\right)$ was represented at bands around $1424 \mathrm{~cm}^{-1}$ and $1381 \mathrm{~cm}^{-1}$.
Stretching of the $\mathrm{C}-\mathrm{O}-\mathrm{C}$ was appeared around band $1152 \mathrm{~cm}^{-1}$ which agreed with Dong et al. (2001); Zvezdova (2010); Liu et al. (2013); Subhapradha et al. (2013); Hafsa et al. (2014) and Kaya et al (2015).

According to the results of Dong et al. (2001); Zvezdova (2010); Zhang et al. (2011); Liu et al. (2013) and Kaya et al. (2015), the stretching of hydroxyl groups of $\mathrm{C}-\mathrm{OH}$ was observed at bands around $1091 \mathrm{~cm}^{-1}$ and $1035 \mathrm{~cm}^{-1}$.

The stretching of pyranose skeletal ring was appeared at band $896 \mathrm{~cm}^{-1}$, this result was corresponded with Dong et al. (2001); Zvezdova (2010); Zhang et al. (2011); Kaya et al. (2015). According to the previous discussed data for the well-defined chitosan, the Fourier transform infrared (FT-IR) confirmed the presence of main functional groups of chitosan in tested sample.

According to dynamic light scattering (DLS) analysis, the mean diameter of chitosan nanoparticles is $53.59 \mathrm{~nm}$ which indicated the successful preparation of chitosan nanoparticles with a Polydispersity Index (Pdi) value of 0.465 . It was also confirm a very good monodispersity and quality of the chitosan nanoparticulate suspensions (Melo et al, 2000; Chattopadhyay et al, 2007). The number-size distribution of chitosan nanoparticles was in a narrow range of 37.84 to $91.28 \mathrm{~nm}$.

The number-size distribution of chitosan nanoparticles consisted of one major peak of $53.59 \mathrm{~nm}$ for $98.2 \%$ of sample which indicated with transmission electron microscope (TEM) results and a very small secondary peak represented $1.8 \%$ of the sample which was a result of the bimodal droplet size distribution of starting emulsions. The chitosan nanoparticles size determined by dynamic light scattering (DLS) is slightly larger than that by TEM since DLS measures a hydrodynamic diameter.

Similarly with the results of Liu et al. (2001) and Younes et al. (2014), the Klebsiella pneumoniae was inhibited with chitosan. The positive result of antibacterial 
activity of chitosan nanoparticles against Bacillus subtilis in this study was in accordance with the results which have been reported against Bacillus subtilis (Jing et al, 2007; Tayel et al, 2010; Benhabiles et al, 2012) and Bacillus cereus (Liu et al, 2001; Tao et al, 2011; Benhabiles et al, 2012; Younes et al, 2014).

The morphological changes which observed in treated bacteria; Klebsiella pneumoniae and Bacillus subtilis with chitosan nanoparticles involved leakage of cell contents, cell deformation (irregularly shaped) and rupture of cell. The results were corresponded with those of Liu et al. (2004) on Escherichia coli and Staphylococcus aureus, Didenko et al. (2005) on K. pneumoniae and Staphylococcus aureus, Li et al. (2010) on Escherichia coli and Wang et al. (2012) on Xanthomonas axonopodis pv. poinsettiicola strain R22579. In agreement with the data of Tsai and $\mathrm{Su}$ (1999); Zheng and Zhu (2003); Chung et al. (2004); Liu et al. (2004); Li et al. (2010) and Wang et al. (2012), the electrostatic interaction between poly cations of chitosan (Amino groups $-\mathrm{NH}_{3}{ }^{+}$in acetic medium) and anions on bacteria cell wall led to increase the cell permeability and leakage of intracellular substances and finally cell death.

Besides, difference between the diameter of bacteria $(\sim 500 \mathrm{~nm})$ and size of chitosan nanoparticles $(\sim 50 \mathrm{~nm})$ played a co-effect in the mode of action of chitosan nanoparticles. That means the chitosan nanoparticles are ten times smaller than the bacteria which facilitates the penetration of antibacterial agent (chitosan nanoparticles) through the bacteria cell wall and cell membrane.

\section{Conclusion}

The chitosan nanoparticles were prepared and showed antibacterial activity against the tested bacteria; Klebsiella pneumoniae and Bacillus subtilis. The chitosan nanoparticles were increased the permeability of the bacteria and led to leakage of cell contents, cell deformation and rupture of cell, therefore, the chitosan nanoparticles were observed to be a powerful antibacterial agent.

\section{References}

Baxter, A, Dillon, M, Taylor, KA, Roberts, GA, 1992: Improved method for i.r. determination of the degree of $\mathrm{N}$-acetylation of chitosan. Int. J. Biol. Macromol., 14, 3:166-9.

Benhabiles, MS, Salah, R, Lounici, H, Drouiche, N, Goosen, MFA, et al, 2012: Antibacterial activity of chitin, chitosan and its oligomers prepared from shrimp shell waste. Food hydrocoll. 29, 1:48-56.

Chattopadhyay, P, Shekunov, BY, Yim, D, Cipolla, D, Boyd, B, et al, 2007: Production of solid lipid nanoparticle suspensions using supercritical fluid extraction of emulsions (SFEE) for pulmonary delivery using the AERx system. Adv. Drug Deliv. Rev. 59, 6:444-53.

Chung, YC, Su, YP, Chen, CC, Jia, G, Wang, HL, et al, 2004: Relationship between antibacterial activity of chitosan and surface characteristics of cell wall. Acta Pharmacol. Sin. 25:932-6.

Didenko, LV, Gerasimenko, DV, Konstantinova, ND, Silkina, TA, Avdienko, ID, et al, 2005: Ultrastructural study of chitosan effects on Klebsiella and Staphylococci. Bull. Exp. Biol. Med. 140, 3:356-60.

Dong, Y, Xu, C, Wang, J, Wang, M, Wu, Y, et al, 2001: Determination of degree of substitution for $\mathrm{N}$-acylated chitosan using IR spectra. Sci. China, Ser. B, Chem. 44, 2:216-24.

Dutta, PK, Dutta, J, Tripathi, VS, 2004: Chitin and chitosan: Chemistry, properties and applications. J. SCI. IND. RES. 63, 1:20-31.

Gylienë, O, Razmutë, I, Tarozaitë, R, Nivinskienë, O, 2003: Chemical composition and sorption properties of chitosan produced from fly larva shells. Chemija (Vilnius), 14, 3:121-7.

Hafsa, J, Charfeddine, B, Smach, MA, Limem, K, Majdoub, H, et al, 2014: Synthesis, characterization, antioxidant and antibacterial proprieties of chitosan ascorbate. Int. J. Pharm. Chem. Biol. Sci. 4, 4:1072-81.

Hassan, MI, Fouda, MA, Hammad, KM, Basiouny, AL, Kamel, MR, 2013: The ultrastructure of sensilla associated with mouthparts and antennae of Lucilia cuprina. J. Egypt. Soc. Parasitol. 43, 3:777-85.

Helander, IM, Nurmiaho-Lassila, EL, Ahvenainen, R, Rhoades, J, Roller, S, 2001: Chitosan disrupts the barrier properties of the outer membrane of Gram-negative bacteria. Int. J. Food Microbiol. 71, 2:235-44.

Jia, Z, Xu, W, 2001: Synthesis and antibacterial 
activities of quaternary ammonium salt of chitosan. Carbohydr. Res. 333, 1:1-6.

Jing, Y, Hao, Y, Qu, H, Shan, Y, Li, D, Du, R, 2007: Studies on the antibacterial activities and mechanisms of chitosan obtained from cuticles of housefly larvae. Acta Biol. Hung. 58, 1:7586.

Kaya, M, Baran, T, Asan-Ozusaglam, M, Cakmak, YS, Tozak, KO, et al, 2015: Extraction and characterization of chitin and chitosan with antimicrobial and antioxidant activities from cosmopolitan Orthoptera species (Insecta). Biotechnol. Bioprocess Eng. 20, 1:168-179.

Li, XF, Feng, XQ, Yang, S, Fu, GQ, Wang, TP, et al, 2010: Chitosan kills Escherichia coli through damage to be of cell membrane mechanism. Carbohydr. Polym. 79, 3:493-9.

Liu, H, Du, Y, Wang, X, Sun, L, 2004: Chitosan kills bacteria through cell membrane damage. Int. J. Food Microbiol. 95, 2:147-55.

Liu, M, Zhou, Y, Zhang, Y, Yu, C, Cao, S, 2013: Preparation and structural analysis of chitosan films with and without sorbitol. Food Hydrocoll. 33, 2:186-91.

Liu, XF, Guan, YL, Yang, DZ, Li, Z, Yao, KD, 2001: Antibacterial action of chitosan and carboxymethylated chitosan. J. Appl. Polym. Sci. 79, 7:1324-35.

Ma, Z, 2015: Evaluation of antimicrobial activity of chitosan nanoparticles in different matrices from animals with disease. Annual Meeting (July 25-28, 2015). Iafp.

Melo, EP, Fojan, P, Cabral, JMS, Petersen, SB, 2000: Dynamic light scattering of cutinase in AOT reverse micelles. Chem. Phys. Lipids. 106, 2:181-9.

Oduor-Odeto, PM, Struszezyk, MH, Peter, MG, 2005: Characterisation of chitosan from blowfly larvae and some crustacean species from Kenyan marin waters prepared under different conditions. Western Indian Ocean J. Mar. Sci., 4, 1:99-108.

Peter, MG, 1995: Applications and environmental aspects of chitin and chitosan. J. Macromol. Sci., Pure Appl. Chem. 32, 4:629-40.

Qi, L, Xu, Z, Jiang, X, Hu, C, Zou, X, 2004: Preparation and antibacterial activity of chitosan nanoparticles. Carbohydr. Res. 339, 16:2693700.

Rinaudo, M, 2006: Chitin and chitosan: properties and applications. Prog. Polym. Sci. 31, 7: 603-32.

Song, C, Yu, H, Zhang, M, Yang, Y, Zhang,
G, 2013: Physicochemical properties and antioxidant activity of chitosan from the blowfly Chrysomya megacephala larvae. Int. J. Biol. Macromol. 60: 347-54.

Souza, S MD, Monache, FD, Smânia, A, 2005: Antibacterial activity of coumarins. Z. Naturforsch C. 60, 9/10:693-700.

Subhapradha, N, Ramasamy, P, Shanmugam, V, Madeswaran, $P$, Srinivasan, A, et al, 2013: Physicochemical characterisation of $\beta$-chitosan from Sepioteuthis lessoniana gladius. Food Chem. 141, 2:907-13.

Tao, Y, Qian, LH, Xie, J, 2011: Effect of chitosan on membrane permeability and cell morphology of Pseudomonas aeruginosa and Staphyloccocus aureus. Carbohydr. Polym. 86, 2:96974.

Tayel, AA, Moussa, S, Opwis, K, Knittel, D, Schollmeyer, E, et al, 2010: Inhibition of microbial pathogens by fungal chitosan. Int. J. Biol. Macromol. 47, 1:10-4.

Tsai, GJ, Su, WH, 1999: Antibacterial activity of shrimp chitosan against Escherichia coli. J. Food Prot. 62, 3:239-43.

Wang, Y, Li, L, Li, B, Wu, G, Tang, Q, et al, 2012: Action of chitosan against Xanthomonas pathogenic bacteria isolated from Euphorbia pulcherrima. Molecules 17, 6:7028-41.

Wanule, D, Balkhande, JV, Ratnakar, PU, Kulkarni, AN, Bhowate, CS, 2014: Extraction and FTIR Analysis of Chitosan from American cockroach, Periplaneta americana. IJESIT. 3, 3: 299-304.

Younes, I, Hajji, S, Frachet, V, Rinaudo, M, Jellouli, K, et al, 2014: Chitin extraction from shrimp shell using enzymatic treatment: Antitumor, antioxidant and antimicrobial activities of chitosan. Int. J. Biol. Macromol. 69:489-98.

Zhang, A, Qin, Q, Zhang, H, Wang, H, Li, X, et al, 2011: Preparation and characterisation of food-grade chitosan from housefly larvae. Czech J. Food Sci. 29, 6:616-23.

Zhang, W, Zhang, J, Xia, W, 2014: Effect of ball-milling treatment on physicochemical and structural properties of chitosan. Int. J. Food Prop. 17, 1:26-37.

Zheng, LY, Zhu, JF, 2003: Study on antimicrobial activity of chitosan with different molecular weights. Carbohydr. Polym., 54, 4:527-530.

Zvezdova, D, 2010: Synthesis and characterization of chitosan from marine sources in Black Sea. Annual Proceedings," Angel Kanchev" University of Ruse, 49, 9.1:65-69. 


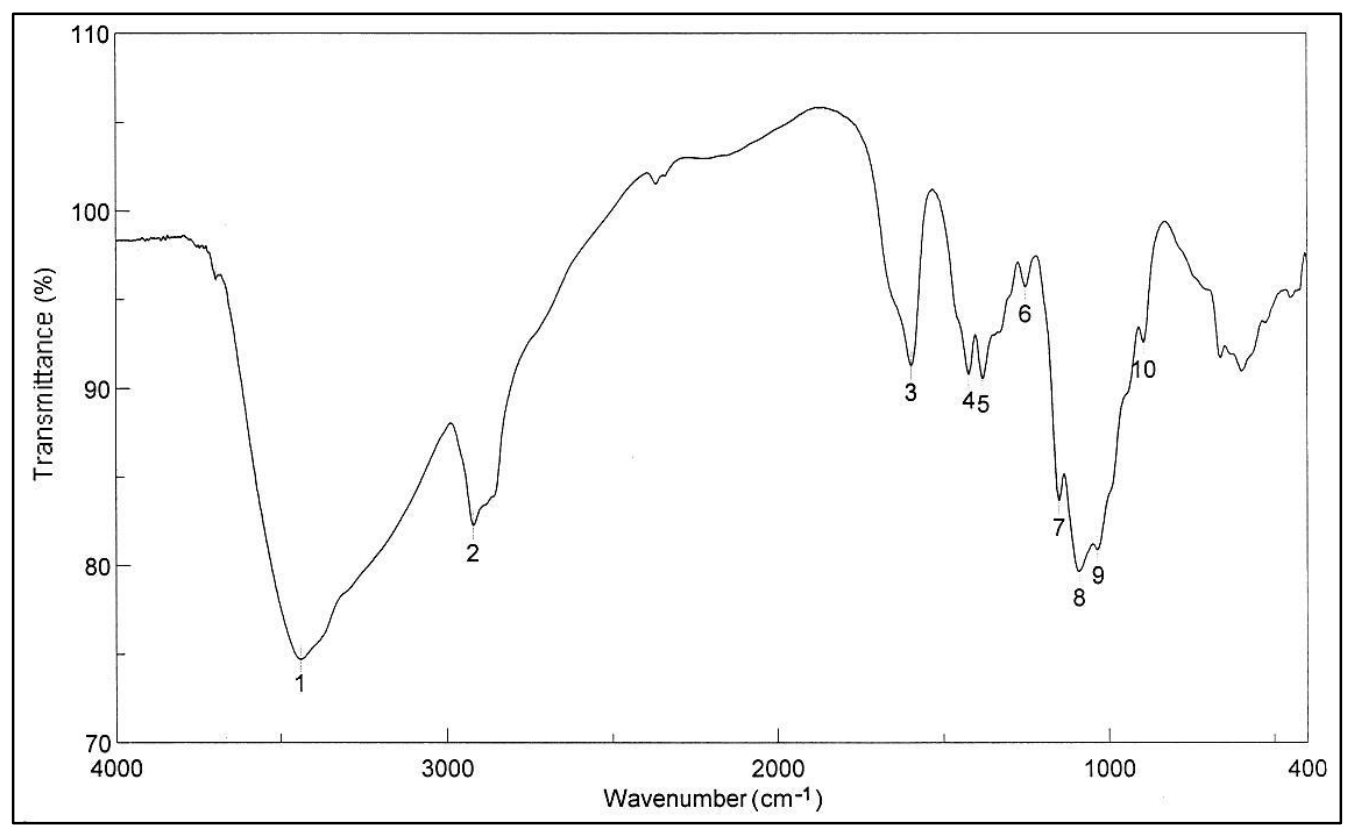

Fig. 1: FT-IR spectrum of chitosan sample prepared from Lucilia cuprina maggots.

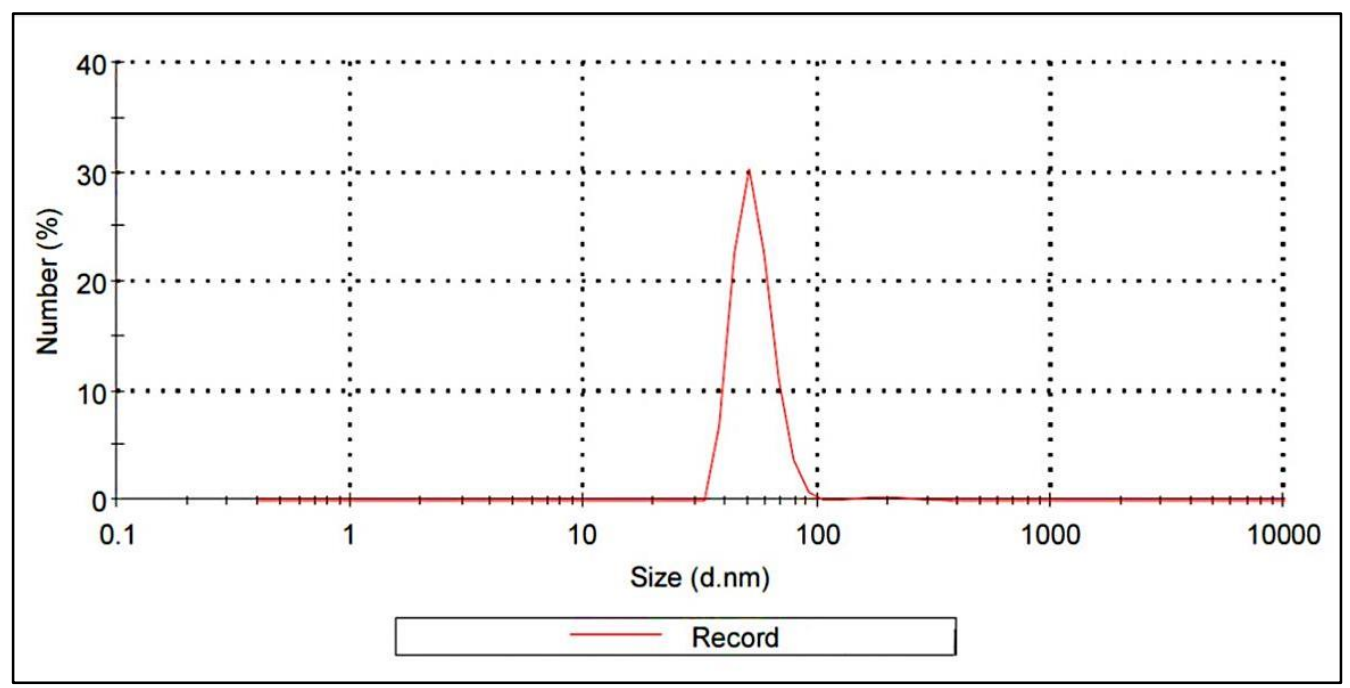

Fig. 2: Sample-size distribution of chitosan nanoparticles batches by dynamic light scattering.

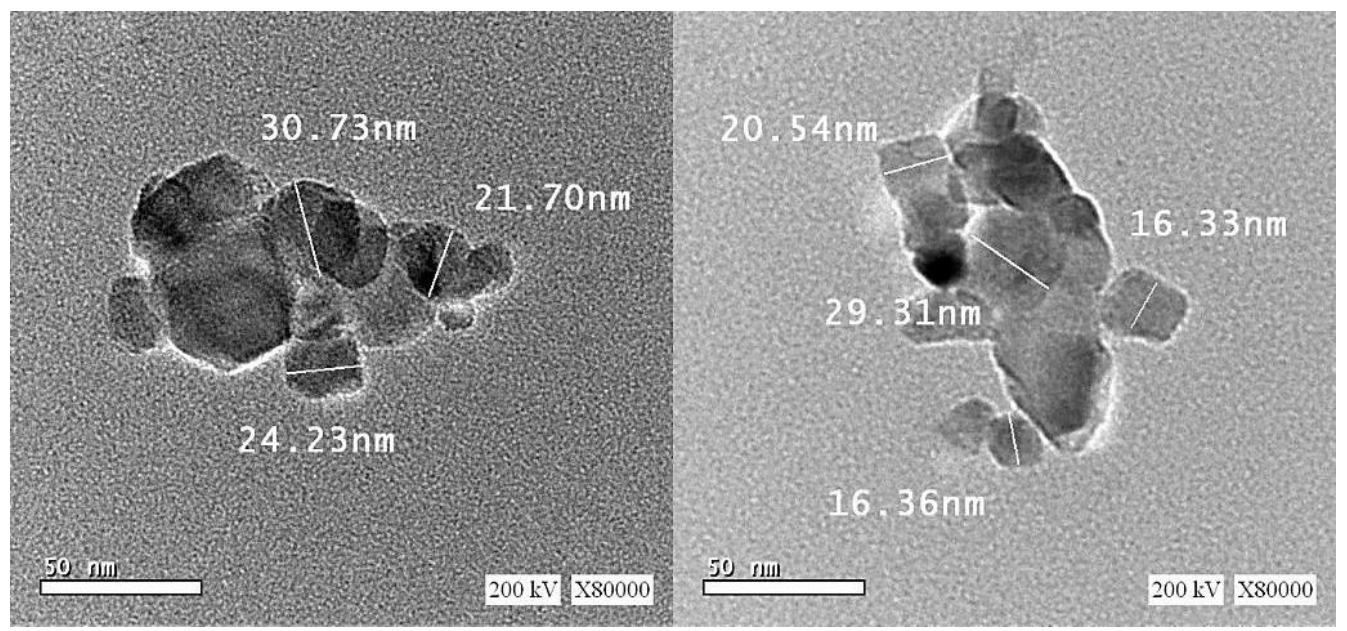

Fig. 3: Transmission electron microscope photomicrograph of chitosan nanoparticles X80000. 


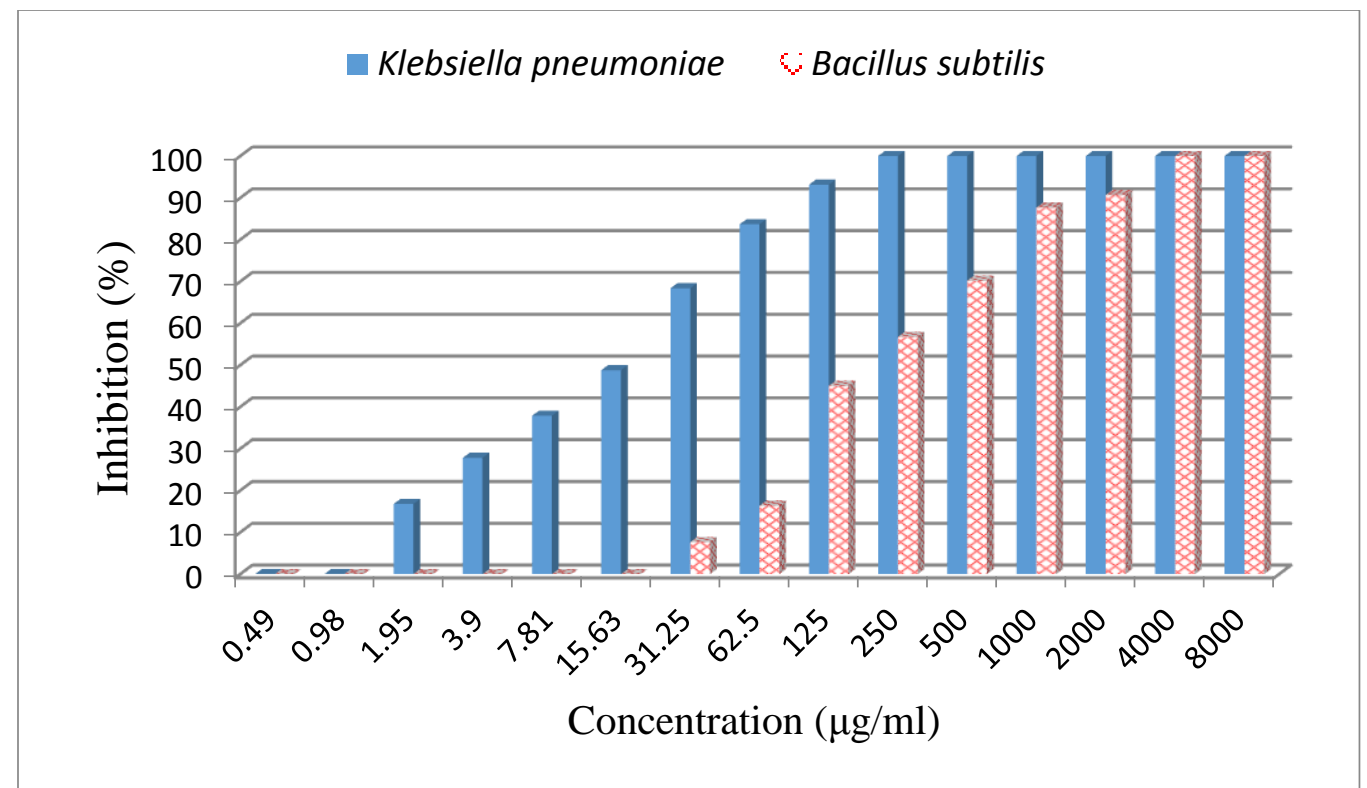

Fig. 4: Antibacterial activities of chitosan nanoparticles against Klebsiella pneumoniae \& Bacillus subtilis

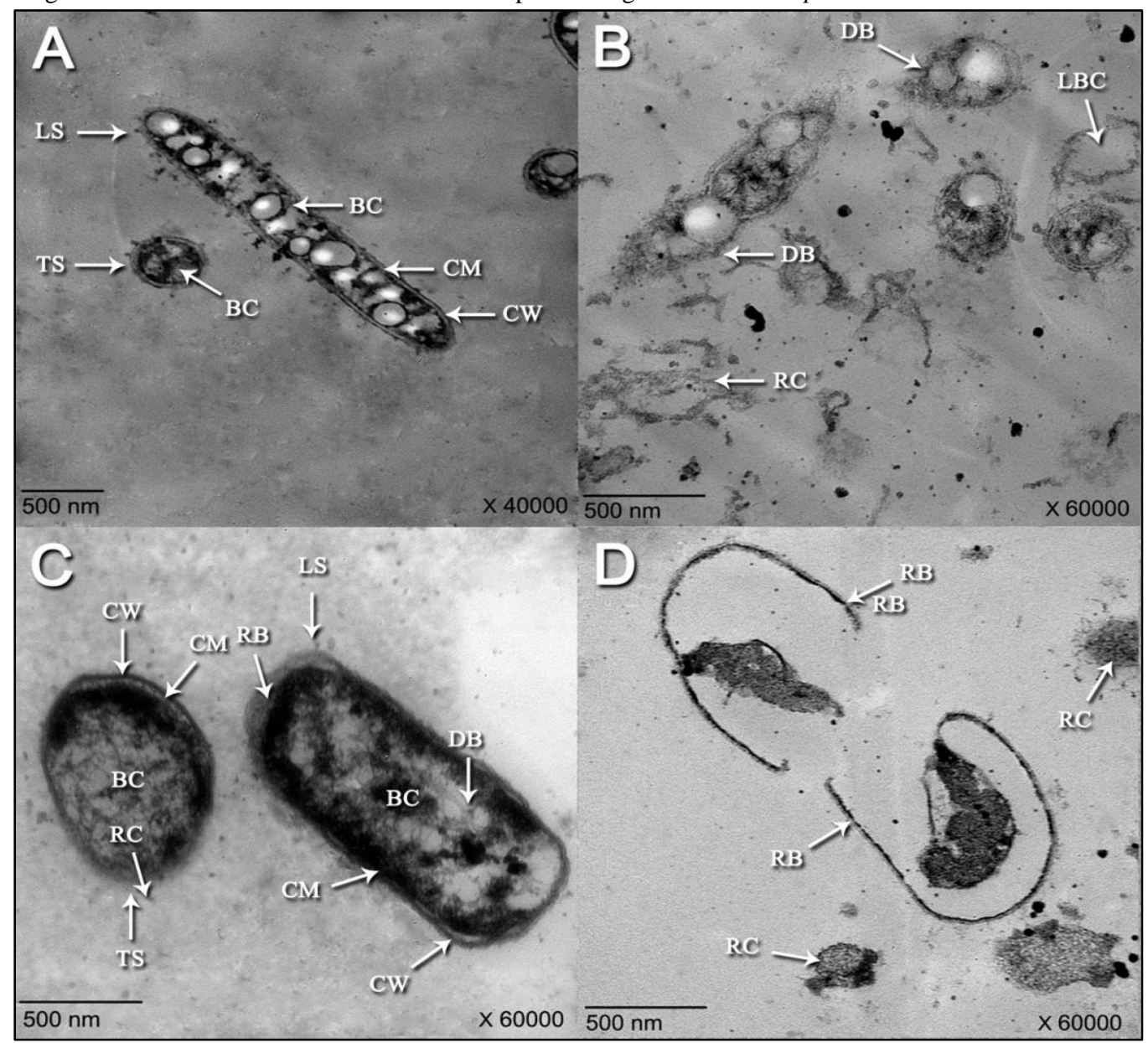

Fig. 5: Transmission electron photomicrographs of treated and untreated Klebsiella pneumoniae and Bacillus subtilis bacteria with chitosan nanoparticles: A- untreated $K$. pneumoniae (Control) X40000, B- treated K. pneumoniae X60000, C- untreated B. subtilis (Control) $\mathrm{X} 60000$ and D- treated B. subtilis $\mathrm{X} 60000 . \mathrm{LS}=$ longitudinal section, $\mathrm{TS}=$ transverse section, $\mathrm{CW}=$ cell wall, $\mathrm{CM}=$ cell membrane, $\mathrm{BC}=$ bacterial contents, $\mathrm{RB}=$ ruptured bacteria, $\mathrm{DB}=$ deformed bacteria, $\mathrm{LBC}=$ leakage of bacterial contents and $\mathrm{RC}=$ released contents. 